\title{
A new gospel for the current context of our Western culture?
}

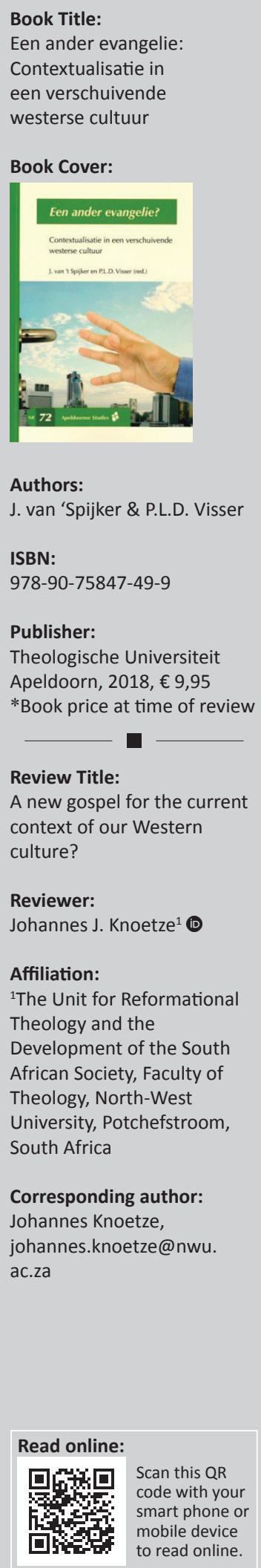

This publication consists of papers delivered at a symposium held at the Theological University of Apeldoorn on 12 May 2017 together with the Christelijke Gereformeerde Kerken in Nederland [Christian Reformed Churches in the Netherlands]. It is very relevant and timely. The symposium was organised to discuss the following question: How does the church bring the gospel of Jesus Christ is a Western secularised and pluralistic society where Christianity is one of many faiths, and 'exclusive humanism' became the way of interpreting life?

The theological discussion was based on the thesis of Gert-Jan Roest, titled 'The Gospel in the Western context. A missiological reading of Christiology in dialogue with Hendrikus Berkhof and Colin Gunton'. In the first chapter, Roest asks the important question: What is the gospel? He makes the conclusion that we need a new contextualisation of the gospel, because guilt no longer represents our deepest question. Contextualising the gospel means that we must discern what the Holy Spirit is doing within this context, and we need criteria from the gospel to discern the working of the Spirit. Identifying the idols of the Western context, Roest develops a soteriology for the context by using the different reconciliation metaphors in the Bible.

The rest of the publication consist of three responses on the work of Gert-Jan Roest. The first is from Michael Mulder with the title 'A different Gospel or the Gospel different?' (Een ander evangelie, of het evangelie anders?) In this chapter, Mulder discusses the fact that the Holy Spirit can bring the church to a new understanding of the gospel when we see the movement of the Spirit outside the walls of the church (p. 35). The important question then is the following: How does our understanding of the context influence our understanding of the gospel? This chapter is written with a clear focus on the work of the trinitarian God over and against the work of man.

The second response from Gerrit Noort is titled 'Contextualisation as tension field between alienation and contours of deliverance' (Contextualisatie als spanningsveld tussen vervreemding en contouren van bevrijding). Noort discusses his views on the work of the Spirit (alienation and deliverance) from an ecumenical perspective by making use of the anthropological views from different writers. A critical question is: Do we first study the context from which a person must be delivered and then we study Scripture? Noort argues that we need to re-think mission, or else people will be alienated from God thinking he is 'behind the time', because he does not attend to the recent changes in our different social contexts. However, culture may not have the last say, as every culture must be placed in the perspective of the 'merciful coming of Christ'.

The third response, titled 'The first context. Proclaiming and contextualising within the Christian congregation' (De eerste context. Verkondiging en contextualisatie binnen de Christelijke gemeente), is written by Rein den Hertog. Arguing from Acts 15:11, attention is given to preaching the gospel in the Reformed tradition. The focus of this chapter is the Christian congregation and the diversity within the congregation. Van Hertog attends to the role of the congregation in the process of contextualising. The congregation is not only the 'object' of the proclamation of the gospel, but also the 'subject'. Contextualisation of the gospel has to do with the proclamation which is first and foremost the responsibility of the congregation and not of the professionals or academics. Further attention must be given to the planting of churches in the Western context.

How to cite this book review: Knoetze, J.J., 2019, 'A new gospel for the current context of our Western culture?', In die Skriflig 53(1), a2466. https://doi.org/10.4102/ids.v53i1.2466

Copyright: @ 2019 . The Authors. Licensee: AOSIS. This work is licensed under the Creative Commons Attribution License. 
The second last chapter is a reply from Gert-Jan Roest and the last chapter contains some remaining questions.

The publication does not attempt to give quick fix answers, but grapples with the different worldviews and needs within our pluralistic and secularised society by asking what the most profound questions of our society are. Although the publication is of high academic standard, it reads easily and challenges the reader to rethink his or her own soteriology.

I would recommend this work to all scholars of mission and practical theology. The publication is suitable for both academics, ministers and church leaders, because it deals with the essence of the gospel message to address the deepest questions of a secularised society. 